\title{
The Relationship Between Service Expectations and Service Quality in University Education
}

\author{
Tran Hoang Minh* \\ Lac Hong University, Bien Hoa, Vietnam \\ *Corresponding author: hoangminh@lhu.edu.vn
}

\begin{abstract}
Along with the rapid development of the scientific and technological revolution, the countries face many opportunities and challenges brought by globalization. Especially with Vietnam, a developing country, challenges are posed in many fields such as policy, infrastructure, labor, human resource education, information technology, finance. Creating high-quality human resources is urgent at present and in the future in Industry 4.0. However, the education of human resources in universities still has some limitations, and management levels have not adequately recognized the relationship between student service expectations about services that higher education institutions have. The study will provide. Therefore, this study will clarify the relationship between the two above problems in the university education environment.
\end{abstract}

Keywords: Service expectation, Service quality, University education.

\section{Introduction}

At present, many lecturers at universities in the South and across the country still maintain old and outdated teaching methods; mainly "monologue" or "teacher reading, writing students"... The application of such teaching methods will not promote students' initiative and activeness in the process of teaching and learning. Therefore, students after graduation do not have the professional skills to meet the requirements of reality. The number of staff members has not met immediate and long-term requirements. The quality of the teaching staff in universities is still lacking, not commensurate with the country's socio-economic development not only in the South, in particular the number of $\mathrm{PhDs}$ or the ratio of doctoral / lecturers is very low (Nguyen Thi Thu Huong, 2012). In general, the current status of faculty capacity development still has many shortcomings and limitations, such as the proportion of lecturers who have not yet received a high degree, their language skills, and informatics skills are still minimal. Many lecturers have not received Access to modern teaching methods and lack practical knowledge; the number of lecturers trained in regular university education is minimal; most lecturers are taught with training classes granting certificates of pedagogical skills. Besides, scientific research capacity is still weak compared to higher education institutions' requirements, and very few scientific works are large-scale, capable of practical application. Some lecturers from sectors have not been adequately arranged with their competencies (Nguyen Minh Tuan, 2019).

\section{Related Concepts}

\section{A. Service Expectations}

Consumption researchers have not explicitly considered the effect of consumer perceptions about products after consumption to a significant extent (Bettman, J.R., 1979). However, some researchers have studied the effect of expectation on product performance on product consumption reviews (Lewin, K. et al., 1994). Researchers have found that a higher level of performance leads to a higher rating if the expectations are kept constant (Oliver, RL, 1977). A conflict arises related to product performance consumption depending on product performance relative to consumer expectations (Hansen, F., 19732). According to Bettman, J.R (1979), the result of a product, the more critical it is to the post-consumer rating, the higher the consumer's participation in the consumption process. Potential customers, for example, are more engaged at a more noticeable level.

Usually, services are products that require high consumer participation in the consumer process. In the relationship between buyer and seller, during production and consumption, at the same time, consumers will often find a lot of resources and activities for exposure and evaluation. For example, think of an airline business or a conference provider. Thus, a consumer's service experience may influence their postconsumer rating of the quality of the service they have experienced, i.e., the service's perceived quality. It makes sense that the perceived quality of service will result from the evaluation process, where the consumer compares their expectations for the service they think has been received, i.e., they think that the Perceived service is compared differently from the Expected service. The result of this process is the perceived quality of service. Therefore, service quality depends on two variables: the expected service and essential service. Olson and Dover (1979) claim that the customer's expectation is their belief before receiving a product, and Parasuraman, Zeithaml, and Berry 1988 confirm that expectation is seen as a consumer's wishes or wishes of what they feel the carrier should offer rather than deliver. For a recent study by Kabul, E., and Acuner, D. (2020) on the assessment of service quality in the 
health sector by service expected and perceived services, the author stated that The actual service quantity is "the assessment of the customer after receiving the service" and the expected quality of the service is defined as the "customer expectation before receiving the service." The difference between the two determines the level of service quality of the organization.

In the context of this study, the author supports the above concepts and can understand the concept of expected services as "services that students expect in terms of quality provided by universities" and Actual services are "services that students receive from universities."

\section{B. Service Quality}

Service Quality (Service Quality) has been a topic of great interest to many scholars and researchers over the years. The concept of service quality is difficult to define because it depends on different contexts and fields. Service quality has been pervasive in various approaches to make it clear, mostly by highlighting customers' perceptions of the service they receive (Parasuraman et al. 1985; Camisón et al. 2007). Hence, well-known researchers such as Lewis and Booms (1983) defined service quality as "a measure of the extent to which the service is provided following customer expectations." On the other hand, Grönroos (1984) refers to service quality as "the result of an evaluation process in which consumers compare their expectations with the service they perceive themselves to have received." Parasuraman et al. (1988) defined service quality as "the consumer's assessment of a unit's overall superiority."

Moreover, some other researchers said that service quality is: "perceived quality" of services, which is different from "objective or actual quality" because it is based on consumer judgment. Used (Lee and Hwan, 2005); Meanwhile, Spathis et al. (2004) defined service quality as "the attitude to form customers' assessment of the overall service." In the same vein, Fogli (2006) states that service quality is "an attitude or a comprehensive assessment of a particular service and a cognitive judgment." Furthermore, it is the "fulfillment of customer expectations (Al-Tamimi et al., 2009), representing "superiority or excellence perceived by the customer" and "the product of endeavor. However, every member of the investment organization aims to satisfy customers" (Legcevic, 2008).

Also, Asubonteng et al. (1996) define service quality as "the degree to which a service meets the customer's needs or expectations of the customer." Lovelock and Wirtz (2011) further describe service quality as a modern concept used by business customers to rate and compare with other service providers. Sultan and Wong (2012) say that service quality is the primary concern of organizations worldwide; this is essential because the quality of service is the only difference between the global market's services. According to Apte (2004), service quality is defined as a service enterprise's ability to satisfy the needs and wants of its customers. For Foundry Rayyani and Widya Silfianti (2020), the definition of service quality focuses on efforts to meet the customer's needs and wants and the accuracy of the delivery to balance customer expectations. Service quality is the level of excellence expected. It is controlled through the degree of excellence in meeting the customer's wishes.

Thus, defining the quality of service is very difficult and depends on each specific field and context. In the context of this study, the author supports the views of some previous researchers. The author also argues that service quality is "the overall customers' assessment as products or service against their expectations of that product or service."

The paper approaches the concept of perceived service quality from Parasuraman et al. $(1985,1988)$ and Zeithaml et al. (1990). Accordingly, perceived service quality results from a comparison between the customer's expected service and their actual perception of the actual results. At the same time, this perception is seen as a comprehensive assessment of the service (Parasuraman et al., 1988). From the same approach, perceived service quality also becomes an overall assessment of whether a product or service is good or bad (Athiyaman, 1997).

\section{The relationship between service expectations and service quality}

The structure of expectation plays an essential role in customer assessment of service quality, which is supported and confirmed by many researchers (Gronroos, 1982; Lehtinen and Lehtinen, 1982; Parasuraman, Zeithaml, and Berry, 1985; 1988; Brown and Swartz 1989) also supporting the hypothesis related to service expectations impacts service quality.

Indeed, there are many different views on the concept of expectation, but it is still possible to generalize this factor as customer confidence before receiving a product (Olson and Dover, 1979). Alternatively, similarly, the expectation is seen as a consumer's wishes or wishes, i.e., what they feel a service provider should offer rather than provide (Parasuraman, Zeithaml, and Berry 1988).

With that approach, expectation serves as the standard or reference point on which the customer will evaluate the product (Zeithaml et al., 1993). In other words, customer expectation becomes a critical factor in forming their perception of service aspects, becoming an essential factor influencing the quality of service that customers feel. In the current research context, the quality of education services perceived by students may be influenced by the students' expectations of entering the school, particularly on the expectations of the quality of service that the university has provided. That is why the study raises the problem: "Service expectations negatively affect the quality of higher education services".

In terms of impact direction, it must be recognized that expectations can negatively affect the customer's perception of service quality. According to expected utility theory, customers' actual value when using a product or service can be completely different from what they expect. In other words, service expectations form separate from the actual service received. Business managers may not translate customer expectations into specifications of service quality or services that customers 
perceive. This gap relates to aspects - design service (Santos et al., 2005).

Actual service may be higher or lower than customers' expectations. The central gap between these two factors becomes the customer's perception of service quality perception. Parasuraman et al. (1988) have stated: "Customer's assessment of service quality results from the comparison between service expectation and actual results of service". The larger the expectation, the smaller the distance between expectations and reality, or even lower than expectations, causing negative perceptions and disappointments in customers.

From the above scientific evidence and the expected utility theory approach, in the context of this research, the problem: "Expected service negatively affects the quality of education services. "learning" is set with the expectation of the opposite effects between the two factors. Specifically, an increase in students' expectations and services, when they are high, will correspondingly reduce students' perceptions of the quality of the university's education services.

\section{Conclusion}

For the image of the expected service on the quality of higher education service is the inverse (negative) relationship that the study identified can be explained by the nature of the expected service as the students' expectations about the services that higher education institutions will provide. However, educational institutions with adequate financial resources and great concern for customer satisfaction invest in a full range of services provided to students. Conversely, institutions with insufficient financial resources or little interest in students will have less of the services provided to students that will adversely affect student expectations.

\section{References}

[1] Nguyễn Thị Thu Hương "Xây dựng đội ngũ giảng viên trong trường đại học - Thực trạng và giải pháp", Tạp chi Khoa học ĐHQGHN, Luật học, No. 28, pp. 110-116, (2012).
[2] Nguyễn Minh Tuấn "Thực trạng phát triển đội ngũ giảng viên khối ngành kỹ thuật ở các trường đại học vùng đồng bằng sông cửu long theo tiếp cận năng lực", Tạp chi khoa học, Tập 48, Số 1B, tr. 51-60 (2019).

[3] Bettman, J.R., "An in formstion Processing Theory of Consumer Choice, Reading, Mass.", Addison- Wesley, p. 275, 1979.

[4] Lewin, K. et af., "Level of Aspiration", in Hunt, J.M. (ed), Personalit f' and Behaviour Disorders, Vol. 1, New York, Ronalds, 1944.

[5] Cardozo, R.N., "An Experimental Study of Consumer Effort, Expectation and Satisfaction", Journal of Marketing Research, August, 1965.

[6] Cohen, J. and Goldberg, M.E., "The Effects of Brand Familiarity and Performance upon Post-Decision Product Evaluation", Paper presented at the American Marketing Association's Workshop on Experimental Research in Consumer Behaviour, Ohio State University, 1969.

[7] See Oliver, R.L., op. cit., 1977.

[8] Hansen, F., "Consumer Choice Behaviour: A Cognitive Theory, New York", The Free Press, p. 179, 1972.

[9] Grönroos, C. (1984). "A service quality model and its marketing implications. European Journal of Marketing, 18(4), 36-44.

[10] Lee, M. C., and Hwan, I. S, "Relationships among Service Quality, Customer Satisfaction and Profitability in the Taiwanese Banking Industry”, International Journal of Management, 22 (4), 635-648, (2005).

[11] Spathis, C., Pteridou, E., and Glaveli, N, "Managing service quality in banks: customers' gender effects". Managing Service Quality, 14 (1), 90102, (2004).

[12] Legcevic, J., "Measuring Customer Satisfaction and Service Quality: The Case of Croatia", Journal of American Academy of Business, Cambridge, 14(1), 123-130, (2008).

[13] Asubonteng P., McCleary K. J. \& Swan, J.E., "SERVQUAL Revisited: A critical review of service quality". The journal of services marketing, 10(6), 62-81, (1996).

[14] Lovelock, C., \& Wirtz, J., "Services marketing: People, technology, strategy (7th ed.)". Pearson Education Limited, (2011).

[15] Sultan, P., \& Wong, H. Y., "Service quality in a higher education context: An integrated model", Asia Pacific Journal of Marketing and Logistics, 24(5), 755-784, (2012)

[16] Findry Rayyani \& Widya Silfianti, "Student Satisfaction Evaluation Towards BPS\&K 1 Jakarta Senior High School Education Services Using Importance Performance Analysis Method", Vol. 02, No. 3, pp. 259-268, (2020).

[17] Zeithaml, V. A., Berry, L. L., \& Parasuraman, A., "The Nature and Determinants of Customer Expectations of Service" Journal of the Academy of Marketing Science, 21(1), pp. 1-12, (1993).

[18] Santos, G., Marques, C. S., Justino, E., \& Mendes, L., "Understanding social responsibility's influence on service quality and student satisfaction in higher education", Journal of Cleaner Production, 256, 120597, (2020).

[19] Parasuraman, A., Zeithaml, V. and Berry, L., "SERVQUAL: a Multipleitem scale for measuring consumer perceptions of service quality", Journal of Retailing, Vol. 64 No. 1, pp. 2-40, (1988).

[20] Parasuraman, A., Zeithaml, V. and Berry, L., "Refinement and reassessment of the SERVQUAL scale", Journal of Retailing, Vol. 67, pp. 4, 420-450, (1991). 